\title{
WORKING OUT OF HEALTH RELATED POWER LIFTING TRAINING PROGRAM FOR FIRST YEAR STUDENTS WITH MUSCULAR SKELETAL APPARATUS AFFECTIONS
}

Zhen Qiang San

Kharkov State Academy of Physical Culture

\begin{abstract}
Purpose: substantiation and working out of program for health improvement of first year students with muscular skeletal apparatus affections by power lifting means. Material: in experiment, which lasted one year, 24 first year students with muscular skeletal apparatus affections participated (two groups, 12 persons in each). The students' age was 18-20 years old. Results: optimal correlation of specific and non-specific loads $-60 \%: 40 \%$ was found. The worked out complex of exercises for training of bench press barbell technique includes the following: special warming up exercises, exercises on special simulators and exercises with weights. As general physical training it is recommended to use complex of commonly accepted exercises. Conclusions: application of the worked out program ensures formation of steady interest to physical exercises' practicing, strengthening of health, replenishment of motor skills' base, training of motor qualities and functional fitness. Besides, it facilitates more effective students' social adaptation in collective.
\end{abstract}

Key words: experiment, health, power lifting, program, motor skills, students, testing.

\section{Introduction}

At modern stage of Ukraine development the problem of students' health improvement is still rather acute [7,8, 20]. Diseases, connected with muscular skeletal apparatus (MSA) disorders, are the most often [19, 21, 29]. Such students additionally have problems with social adaptation in universities $[11,21]$. Problem of social adaptation is the most acute for $1^{\text {st }}$ year students with MSA affections. Sociological research, conducted by S.V. Korolinskaya (2011) [13] showed a number of social psychological factors, which determine effectiveness of students' adaptation to teaching educational process. The author recommends wide usage of physical culture for adaptation period's shortening and for increasing mental and physical workability.

The research by E.V. Makarova (2012) [16] permitted to mark out directions of students' adaptation to future profession. It was found that integrated and inclusive educational environment is an optimal form for provisioning of disabled youth with conditions for self expression, self-perfection and self-creation; for realization of rights and potentials, formation of personal significance and usefulness feeling.

Among many researches, devoted to problems of first year students' adaptation to HEE educational environment we can mark out the following works: Ye.L. Tomkiv (2008) [27], Ye.A. Belikova and O.L. Omelchenko (2010) [3], V.N. Kornilova and L.A. Prokopenko (2014) [12], T.Yu. Zharov et al. (2015) [10].

In the work by V.A. Druz et al. (2010) [9] directions of solution of re-socialization problems for disabled with MSA disorders are elucidated. The authors note demand in maximal consideration of kind of disease, degree of muscular skeletal apparatus disorders, individual features of physical loads' endurance. Besides, they supply recommendations on application of highly emotional exercises and games that facilitate more effective influence of used physical exercises.

As per specialists' recommendations one of ways of this problem's solution is practicing of different kinds of sports (power lifting, for example) [1, 8, 18]. In the work by Yu.V. Gordiyenko (2015) [6] it is shown, that power lifting trains girl students' ability to think independently; facilitates increase of self control and self analysis. It was found that correctly built training program facilitates strengthening of motivation for acquiring and mastering knowledge by girl students.

Internet information resources about power lifting are significant base for construction of training programs for students. For example, A.I. Stetsenko (2011) [25] thinks, that in Ukrainian speaking Internet environment power lifting is paid much more attention, comparing with other power kinds of sports. It promotes construction of students' power lifting program with better quality.

Speaking about students' power lifting, it is also necessary to pay attention to works by I.N. Manko (2009) [17], M.Yu. Minova (2010) [18], A.V. Gorbunova [5], Ye.V. Kurmayeva (2013) [14].

Alongside with it, power lifting trainings of students with MSA disorders have certain peculiarities. For example, in researches fulfilled by V.S. Lobko (2015) [15] we found distinctions between psycho-physiological characteristics, indicators of psychic state and features of students' personalities, depending on power lifting training experience. It was stated, that under influence of systemic power lifting trainings indicators of functional mobility and strength of nervous processes improve. The author also notes, that rising of students' sportsmanship is accompanied by noticeable improvement of practically all indicators.

(C) Zhen Qiang San, 2015

http://dx.doi.org/10.15561/20755279.2015.0508 
By data of M.A. Al-Soub, R.V. Chudna and A.Kh. Khasan Faisal [2, 28, 29] it was found, that researches of the mentioned problem are of fragmentary character. Analysis of researches on problem of health related power lifting programs for first year students with MSA affections points at demand in additional researches.

\section{Purpose, tasks of the work, material and methods}

The purpose of the work is to work out program of power lifting health related trainings for first year students with affections of muscular skeletal apparatus.

Material and methods of the research: in experiment, which lasted one year, 24 first year students with muscular skeletal apparatus affections participated (two groups, 12 persons in each). The students' age was 18-20 years old

According to the tasks of the research we conducted experiment, which lasted one year. As a hypothesis we assumed possibility of working out of power lifting training program, which would consider correlation of specific and non specific training means in year cycle of first year students with MSA affections. In this connection we conducted pedagogic experiment with participation of two groups, consisting of first year students with MSA affections, who did not practice physical culture or sports before entering university. Both groups consisted of 12 students and had no confident differences by main indicators: functional, physical and psychological fitness. In the course of experiment groups 1 and 2 fulfilled different correlation of specific and non specific loads: in group $1-60 \%: 40 \%$; in group $2-$ $70 \%: 30 \%$.

Results of the research

More specific of training means in both groups is given in table 1 .

Table 1. Year volumes of main training means of $1^{\text {st }}$ year students - power lifters in group 1 and 2.

\begin{tabular}{|c|c|c|}
\hline Min means of training & Group 1 & Group 2 \\
\hline Quantity of trainings & 120 & 120 \\
\hline Quantity of training hours & 216.4 & 217.2 \\
\hline Quantity of competitions & 4 & 4 \\
\hline Theoretical training, hours & 4 & 4 \\
\hline Quantity of barbell lifting, & 2411.5 & 2656.7 \\
\hline \multicolumn{3}{|l|}{ Including with intensity: } \\
\hline up to $50 \%$ from maximal, $\%$ & 40 & 32 \\
\hline up to $60 \%$ from maximal, $\%$ & 20 & 22 \\
\hline up to $70 \%$ from maximal, $\%$ & 20 & 22 \\
\hline up to $80 \%$ from maximal, $\%$ & 10 & 12 \\
\hline up to $95 \%$ from maximal, $\%$ & 10 & 12 \\
\hline $\begin{array}{l}\text { Means of general physical training, including } \\
\text { exercises by individual plan, hours }\end{array}$ & 91.2 & 82.1 \\
\hline Exercises in game form and recreation, hours & 3.5 & 3.5 \\
\hline
\end{tabular}

In summer period of experiment as specific loads we used complex of exercises for training of barbell bench press technique, special warming up exercises, exercises on special simulators and exercises with weights. As general training means, in the course of all experiment, we used complex of commonly accepted exercises. Testing of $1^{\text {st }}$ and $2^{\text {nd }}$ groups' students, conducted at the end of experiment, permitted to register noticeable progress of functional, physical and psychological fitness indicators. For example, in $1^{\text {st }}$ group volume of chest in inhale, exhale and in pause increased accordingly by $5.8 ; 5.7 ; 7.5 \%(\mathrm{p}<0.05)$. Vital capacity of lungs increased statistically significantly by $427.2 \mathrm{ml}$. Significant improvement of respiratory system's functional state was also registered in Stange's test $-19.9 \%$ and in Genchi's test - by 37.9\% ( $\mathrm{p}<0.05$ ). Quantity of front and back claps (students' speed qualities) increased by $21.6 \%$ ( $\mathrm{p}$ $<0.05$ ). Final results in throw of medicine ball from behind the head - forward and from behind the head - backward increased accordingly by 16.8 and $13 \%$. The highest progress (by $46.7 \%$ ) was noticed in main competition exercise bench press of barbell. Significant progress of motor and coordination potentials was accompanied by perfection of psycho-physiological indicators. For example, students of $1^{\text {st }}$ group demonstrated reduction of simple visual response latent period by $22.2 \%(\mathrm{p}<0.05)$. Accordingly latent periods of choice of one from three irritators improved statistically 
significantly by 19.6 and $28.2 \%$. Widening of students - power lifters' circle of conditional reflex links reflected in indicators of functional mobility (by 10.5\%) and power of nervous processes (by 39\%). At the end of experiment statistically significant positive changes were registered in $1^{\text {st }}$ group by such, important for disabled, characteristics as psychic state and properties of personality.

Analysis of $2^{\text {nd }}$ group students' psycho-physiological indicators also showed their improvement at the end of experiment. Though, we did not register statistically significant changes $(p>0.05)$. Experimental data permitted also to find that group 1 had noticeable superiority by indicators of respiratory system's functional state. For example, volume of chest at inhale, exhale and pause in $1^{\text {st }}$ group was $82.7 \mathrm{~cm}, 72.4 \mathrm{~cm}, 77.3 \mathrm{~cm}$ in contrast to $79 \mathrm{~cm}, 70.1 \mathrm{~cm}, 72.4 \mathrm{~cm}$ in group 2. Also in group 1 there is higher level of vital capacity of lungs: $2718.9 \mathrm{ml}$ in contrast to $2583.3 \mathrm{ml}$ in $2^{\text {nd }}$ group $(\mathrm{p}<0.05)$. Comparison of students' physical fitness at the end of experiment showed the following (see table 2). Power lifters of $1^{\text {st }}$ group demonstrated higher results in tests for quickness and speed power. With it differences between two groups were statistically significant. Statistically significant distinctions between groups were also registered in indicators of static endurance of strong and weak hands. In other tests we did not notice statistically significant difference ( $\mathrm{p}>0.05)$.

Table 2. Sport results and motor qualities indicators of students - power lifters with MSA disorders in group 1 and 2 at the end of experiment

\begin{tabular}{|c|c|c|c|c|c|}
\hline \multirow[t]{2}{*}{ The tested indicators } & \multicolumn{2}{|c|}{$\begin{array}{l}\text { Group } 1 \\
(n=12)\end{array}$} & \multirow[t]{2}{*}{$\mathbf{p}$} & \multirow{2}{*}{$\begin{array}{l}\begin{array}{l}\text { Group } 2 \\
\text { (n=12) }\end{array} \\
\bar{X}\end{array}$} & \multirow[b]{2}{*}{ m } \\
\hline & $\bar{X}$ & m & & & \\
\hline $\begin{array}{l}\text { Front and back claps during } 10 \text { sec., } \\
\text { quantity }\end{array}$ & 23.15 & 0.21 & $<0.05$ & 20.14 & 0.26 \\
\hline $\begin{array}{l}\text { Forward throw of medicine ball from } \\
\text { behind the head, } m\end{array}$ & 4.52 & 0.03 & $<0.05$ & 4.21 & 0.05 \\
\hline $\begin{array}{l}\text { Backward throw of medicine ball from } \\
\text { behind the head, } m\end{array}$ & 4.38 & 0.03 & $<0.05$ & $4, \backslash .11$ & 0.03 \\
\hline $\begin{array}{l}\text { Bench press of barbell in lying position, } \\
\mathrm{kg}\end{array}$ & 64.53 & 2.17 & $>0.05$ & 66.91 & 2.11 \\
\hline $\begin{array}{l}\text { Strong arm's mobility in shoulder joint, } \\
\text { degrees }\end{array}$ & 70.18 & 2.18 & $>0.05$ & 70.92 & 2.46 \\
\hline $\begin{array}{l}\text { Weak arm's mobility in shoulder joint, } \\
\text { degrees }\end{array}$ & 69.53 & 2.68 & $>0.05$ & 69.87 & 2.84 \\
\hline Static endurance of strong hand, sec. & 11.4 & 0.02 & $<0.05$ & 8.1 & 0.03 \\
\hline Static endurance of weak hand, sec. & 10.1 & 0.01 & $<0.05$ & 6.9 & 0.02 \\
\hline \multirow{2}{*}{$\begin{array}{l}\text { Total indicator of } \\
\text { strength of } 5 \text { muscular } \\
\text { groups of strong arm, } \\
\text { kg }\end{array}$} & 169.8 & 3.96 & $>0.05$ & 172.9 & 4.29 \\
\hline & 2.70 & 0.03 & $>0.05$ & 2.79 & 0.04 \\
\hline \multirow{2}{*}{$\begin{array}{l}\text { Total indicator of } \\
\text { strength of } 5 \text { muscular } \\
\text { groups of weak arm, } \\
\text { kg }\end{array}$} & 157.5 & 3.75 & $>0.05$ & 161.3 & 3.84 \\
\hline & 2.51 & 0.04 & $>0.05$ & 2.61 & 0.03 \\
\hline
\end{tabular}


At the end of experiment in both groups all psycho-physiological indicators improved. With it, more positive changes were in power lifters of group 1. Calculation of confidence of differences between indicators of group 1 and group 2 showed statistically significant superiority of group 1. Exclusion was indicator of latent period response when choosing one irritator from three ( $p>0.05)$. Testing of psychic state and personalities' features in group 1 and group 2 at the end of experiment showed that in group1 there was higher level of nervous psychic stability in motivation for success and avoiding failure; besides there were statistically significant differences between groups.

\section{Discussion}

Final data of experiment confirmed actual materials of pedagogues, psychologists, medical workers, specialists in therapeutic physical culture, conches of sports for disabled about effective impact of regular physical exercises' practicing on physical health of disabled [1, 4, 7, 11, 21, 26, 31, 33]. In our experiment we realized, to some extent, principle, offered by L. Vygotskiy:

1) Observation of pedagogic actions' orientation on weakening of physical and psychic defects of children with health problems;

2) Active development of cognitive functioning, psychic processes, physical abilities and moral qualities of children [22-24, 30].

Results of our researches supplement the data of other authors (Trinkaus E., Rhoads M.L., 1999 [41]; Rossouw F., Krüger P.E., Rossouw J., 2000 [39]; Keogh J.W.L., Hume P.A., Pearson S.N., Mellow P., 2007 [36]; Jensen A.M., 2010 [35]; Hale B.D., Roth A.D., DeLong R.E., Briggs M.S., 2010 [34]; Kozub F.M., Brusseau T.A., 2012 [37]; Lewis C., 2015 [38]) about positive influence of power lifting specific loads on students' health.

Results of our researches also confirmed the data of V.S. Lobko (2015) [15] that systemic power lifting trainings facilitate improvement of functional mobility and nervous processes' power indicators.

The received by us results permit to speak about more effective influence of power lifting means on indicators of students with MSA disorders. Such influence is ensured by:

1) Correlation of specific and non specific loads $-60 \%: 40 \%$;

2) Application of worked out complex of exercises for training barbell bench press technique, which included special warming up exercises, exercises on special simulators and exercises with weights.

\section{Conclusions:}

1. It was found that recent years methodic of disabled health improvement through trainings in separate kinds of sports has been being prevailed. In our research we tried to substantiate program of health related power lifting trainings for first year students with disorders of muscular skeletal apparatus.

2. In the course of experiment we solved the task - determination of optimal parameters of physical loads in year cycle of power lifting training of students with MSA affections. The conducted during one year experiment permitted to substantiate optimal program of power lifting trainings for first year students with MSA disorders, which envisages application of specific and non specific loads in proportion $60 \%$ and $40 \%$. Application of the worked out program ensures formation of steady interest to physical exercises' practicing, development of motor skills and functional fitness as well as facilitates more effective students' social adaptation in collective.

The prospects of further researches in this direction can be connected with studying of competition loads influence on students-power lifters' organism.

\section{Acknowledgement}

The topic of our research is an integral part of scientific research work's program of Kharkov State academy of physical culture. The work has been fulfilled in compliance with "Combined plan of scientific research work in sphere of physical culture and sports for 2011-2015" by topic 2.4 "Theoretical-methodic principles of individualization in education and sports" (state registration N 0112U002001) as well as in compliance with scientific-research project for 2013-2015 "Theoretical-methodic provisioning of formation of personality's healthy life style in conditions of educational establishment and in context of European integration" (state registration N 0114U001781) of Ministry of education and science of Ukraine.

\section{Conflict of interests}

The author declares that there is no conflict of interests. 


\section{References:}

1. Vinnik DP. Adaptivnoe fizicheskoe vospitanie i sport [Adaptive physical education and sports], Kiev: Olympic Literature; 2010. (in Russian)

2. Al'-Soub MA. Kontrol' velichini fizichnikh navantazhen' futbolistiv z naslidkami ditiachogo cerebral'nogo paralichu [Control of physical loads values of football players with after-effects of cerebral palsy]. Visnik Chernigivs'kogo nacional'nogo pedagogichnogo universitetu imeni Tarasa Shevchenka, 2011;91:203-204. (in Ukrainian)

3. Belikova EA, Omel'chenko OL. K voprosu o sostoianii zdorov'ia studentov I kursa v period adaptacii k usloviiam VUZA [On the problem of s1st year students' health condition in adaptation period to HEE conditions]. Zdorov'e i obrazovanie v XXI veke, 2010;12(7):334. (in Russian)

4. Valeev N, Zakharova L, Ganzina N. Poisk novykh form fizkul'turno-rekreativnoj deiatel'nosti v processe reabilitacii invalidov s posledstviiami detskogo cerebral'nogo paralicha [Searching of new forms of physical culture - recreation activity in rehabilitation of disabled with after-effects of cerebral palsy]. Mezhdunarodnyj Kongress "Chelovek v mire sporta" [International congress "Man in the world of sports"]. Moscow; 1998. p. 524-525. (in Russian)

5. Gorbunov AV. Pauerlifting v sisteme fizicheskogo vospitaniia studentov [Power lifting in system of students' physical education]. Izvestiia Volgogradskogo gosudarstvennogo tekhnicheskogo universiteta, 2012;9(11,98):38-41. (in Russian)

6. Gordienko YV. Theoretical training in physical education of higher educational establishments' girl students. Physical education of students, 2015;4:3-9. http://dx.doi.org/10.15561/20755279.2015.0401

7. Guzij OV. Zasobi fizichnogo vikhovannia u fizichnij reabilitacii ditej z cerebral'nim paralichem [Physical education means in physical rehabilitation of children with cerebral palsy], Lviv: Ukrainian technologies; 2002. (in Ukrainian)

8. Denisenko N. Osoblivosti rivnia zdorov'ia, fizichnoi pidgotovlenosti, samopochuttia ta vedennia zdorovogo sposobu zhittia v uchniv zagal'noosvitnikh shkil i gimnazij [Specific features of health, physical fitness, self feeling and practicing of healthy life style of comprehensive schools' and gymnasiums' pupils]. Slobozhans'kij naukovo-sportivnij visnik, 2007;3:44-46. (in Ukrainian)

9. Druz' VA, Klimenko AI, Pomeshchikova IP. Social'naia adaptaciia lic s narusheniiami oporno-dvigatel'nogo apparata sredstvami fizicheskogo vospitaniia [Social adaptation of patients with muscular skeletal apparatus disorders by means of physical education]. Physical education of students, 2010;1:34-37.

10. Zharova TIu, Kulikov NM, Ekhlakova MA. Obshchestvennaia napravlennost' lichnosti studenta-pervokursnika $\mathrm{v}$ processe adaptacii $\mathrm{k}$ obucheniiu v VUZE [Social orientation of first year student's personality in process of adaptation to studying at HEE]. Diskussiia, 2015;1(53):127-131. (in Russian)

11. Ivanova IB. Do pitannia social'no-psikhologichnoi adaptacii molodikh invalidiv [On the problem of socialpsychological adaptation of young disabled]. Molodizhni problemi v Ukraini: stan ta shliakhi virishennia [Problems of youth in Ukraine: situation and ways of solution]. Lviv; 1997. P. 81-84. (in Ukrainian)

12. Kornilova VN, Prokopenko LA. Adaptaciia studentov-pervokursnikov k obucheniiu v vuze cherez sredstva fizicheskoj kul'tury i sporta [Adaptation of first year students to studying at HEE through means of physical culture and sports]. Mezhdunarodnyj zhurnal eksperimental'nogo obrazovaniia, 2014;7(1):50-51. (in Russian)

13. Korolinskaia SV. Nekotorye problemy adaptacii inostrannykh studentov anglijskogo otdeleniia NFAU [Some adaptation problems of foreign students of English department of NPAU]. Physical education of students, 2011;4:48 - 51.

14. Kurmaeva E.V., Fitness - programs as mean of forming of personality physical culture of students. Physical education of students, 2013;1:37-39. http://dx.doi.org/10.6084/m9.figshare.156355.

15. Lobko VS. Psycho-physiological characteristics of students-powerlifters of different training experience, who have affections of muscular skeletal apparatus. Pedagogics, psychology, medical-biological problems of physical training and sports, 2015;5:22-26. http://dx.doi.org/10.15561/18189172.2015.0504

16. Makarova EV. Podkhody $\mathrm{k}$ povysheniiu effektivnosti processa obucheniia i budushchej professional'noj deiatel'nosti studentov s invalidnost'iu [Approaches to increase of effectiveness of training process and future professional functioning of disabled students]. Physical education of students, 2012;5:64-68. 
17. Man'ko IN. Razvitie sily u studentov fizkul'turnykh vuzov na zaniatiiakh po silovoj podgotovke [Development of strength of physical culture HEEs' students at power training classes]. Pedagogics, psychology, medicalbiological problems of physical training and sports, 2009;7:113 - 121.

18. Minov MIu. Pauerlifting kak effektivnoe sredstvo razvitiia fizicheskikh kachestv i ukrepleniia zdorov'ia studentov [Power lifting as effective mean of physical qualities' training and strengthening of students' health]. Vestnik Krasnoiarskogo gosudarstvennogo pedagogicheskogo universiteta im. V.P. Astaf'eva, 2010;2:47-51. (in Russian)

19. Perederij AV. Osoblivosti metodiki tekhnichnoi pidgotovki sportsmeniv-invalidiv z poshkodzhenniami opornorukhovogo aparatu [Specific features of technical training methodic for disabled sportsmen with disorders of muscular skeletal apparatus]. Pedagogics, psychology, medical-biological problems of physical training and sports, 1999;11:9-12. (in Ukrainian)

20. Platonov VN. Obshchaia teoriia podgotovki sportsmenov olimpijskom sporte [General theory of sportsmen's training in Olympic sports]. Kiev: Olympic Literature; 1997. (in Russian)

21. Prokopova LI. Deiaki problemi social'noi reabilitacii invalidiv zasobami fizichnoi kul'turi [Some problems of social rehabilitation of disabled by means of physical culture]. II Vseukrains'ka naukova praktichna konferenciia "Koncepciia pidgotovki specialistiv fizichnoi kul'turi v Ukraini". [2nd All Ukrainian scientific-practical conference "Conception of physical culture specialists' training in Ukraine"]. Kiev; 1996. p. 421-425. (in Ukrainian)

22. Romanova OL. Psikhologicheskoe izuchenie mekhanizmov formirovaniia lichnosti bol'nykh detskim cerebral'nym paralichom [Psychological study of personality's formation mechanisms of patients with cerebral palsy], Narusheniia povedeniia u detej podrostkov [Adolescents' behavior disorders], Moscow; 1982. p. 101107. (in Russian)

23. Sermeev BV, Efimenko NN. Individual'no-differencirovannyj podkhod v processe korrekcii dvigatel'nykh narushenij u detej, stradaiushchikh cerebral'nym paralichom [Individual-differentiated approach in correction of motor disorders of children with cerebral palsy]. Fizicheskoe vospitanie detej v special'nykh shkolakh [Physical education of children in special schools], Bitter; 1980. p. 86-98. (in Russian)

24. Sin'ov VM, Kobernik GM. Osnovi defektologii [Principles of defectology], Kiev: High School; 1994. (in Ukrainian)

25. Stecenko AI. Teoretiko-metodicheskoe obespechenie uchebnogo processa studentov-pauerlifterov $\mathrm{s}$ pomoshch'iu internet-resursov [Theoretical methodic provisioning of students - power lifters' education with Internet resources]. Pedagogics, psychology, medical-biological problems of physical training and sports, 2011;11:118-123.

26. Tikhonova VA, Sidorko IV, Chesnokov GS. Vpliv rozvitku psikhomotornoi funkcii na formuvannia rukhovikh navichok na urokakh fizichnoi kul'turi [Influence of psycho-motor function's development on formation of motor skills at physical culture lessons]. Teoriia ta praktika fizichnogo vikhovannia, 2001;4:8-10. (in Ukrainian)

27. Tomkiv EL. Vzaimosviaz' social'nykh znachenij i cennostej [Interconnection of social meanings and values]. Sovremennye gumanitarnye issledovaniia, 2008;4:185-187. (in Russian)

28. Fajsal AKhKh. Kharakteristika izmenenij psikhofiziologicheskikh pokazatelej u studentov, perenesshikh zabolevanie cerebral'nym paralichom $\mathrm{v}$ processe mnogoletnikh zaniatij legkoatleticheskimi metaniiami [Characteristic of psycho-physiological indicators' changes of students with after effects of cerebral palsy in process of many years trainings of light athletic throws]. Visnik Lugans'kogo nacional'nogo universitetu imeni Tarasa Shevchenka, 2013;8:194-200. (in Russian)

29. Chudnaia RV. Adaptivnoe fizicheskoe vospitanie [Adaptive physical education]. Scientific opinion; 2000. (in Russian)

30. Shapkova LV. Opornye koncepcii metodologii adaptivnoj fizicheskoj kul'tury [Supporting concepts of adaptive physical culture methodology]. Teoriia i praktika fizicheskoj kul'tury, 1998;1:8-19. (in Russian)

31. Shtengerc S. Vpliv fizichnikh vprav na khvoru ditinu [Influence of physical exercises on sick child], Koncepciia rozvitku galuzi fizichnogo vikhovannia i sportu v Ukraini, 1999;1:57-59. (in Ukrainian)

32. Enoka RM. Neuromechanical basis of kinesiology. 2nd ed., Champaign, Leeds: Human Kinetics; 1994.

33. Gage JR. Gate analysis in cerebral palsy. London: Mac Keith Press; 1991. 
34. Hale BD, Roth AD, DeLong RE, Briggs MS. Exercise dependence and the drive for muscularity in male bodybuilders, power lifters, and fitness lifters. Body Image. 2010;7(3):234-239.

35. Jensen AM. A mind-body approach for precompetitive anxiety in power-lifters: 2 case studies. Journal of Chiropractic Medicine. 2010;9(4):184-192.

36. Keogh JWL, Hume PA, Pearson SN, Mellow P. Anthropometric dimensions of male powerlifters of varying body mass. Journal of Sports Sciences. 2007;25(12):1365-1376.

37. Kozub FM, Brusseau TA. Powerlifting. Journal of Physical Education, Recreation \& Dance. 2012;83(3):3441.

38. Lewis C. Another sports drug-testing failure: Australian government policy and powerlifting. International Journal of Sport Policy and Politics. 2015;7(2):233-253.

39. Rossouw F, Krüger PE, Rossouw J. The effect of creatine monohydrate loading on maximal intermittent exercise and sport-specific strength in well trained power-lifters. Nutrition Research. 2000;20(4):505-514.

40. Tremblay L, Proteau L. Specificity of Practice: The Case of Powerlifting. Research Quarterly for Exercise and Sport. 1998;69(3):284-289.

41. Trinkaus E, Rhoads ML. Neandertal knees: power lifters in the Pleistocene? Journal of Human Evolution. 1999;37(6):833-859. 


\section{Information about the author:}

Zhen Qiang San; http://orcid.org/0000-0001-5766-0833; alesik1974@mail.ru; Kharkov State Academy of Physical Culture; Klochkovskaya str. 99, Kharkov, 61022, Ukraine.

Cite this article as: Zhen Qiang San. Working out of health related power lifting training program for first year students with muscular skeletal apparatus affections. Physical education of students, 2015;5:54-61. http://dx.doi.org/10.15561/20755279.2015.0508

The electronic version of this article is the complete one and can be found online at: http://www.sportpedu.org.ua/html/arhive-e.html

This is an Open Access article distributed under the terms of the Creative Commons Attribution License, which permits unrestricted use, distribution, and reproduction in any medium, provided the original work is properly cited (http://creativecommons.org/licenses/by/4.0/deed.en).

Received: 16.08 .2015

Accepted: 29.08.2015; Published: 02.09.2015 